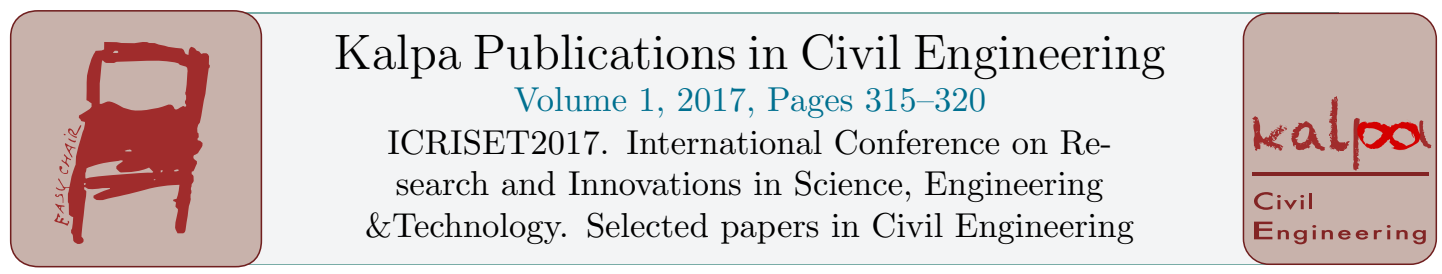

\title{
Static and Modal Analysis of Simply Supported Rectangular Plate By Using ANSYS
}

\author{
Umale Shubhangi Tejrao ${ }^{1}$ and Dr.Shinde Sangeeta $B^{2}$ \\ ${ }^{1}$ P.G Student and ${ }^{2}$ H.O.D \\ Department of Civil Engineering M.G.M'S JNEC AURANGABAD \\ ${ }^{1}$ shubhumale16@gmail.com; ${ }^{2}$ sb_shindedyahoo.com
}

\begin{abstract}
In the present work, Finite element analysis is done by using FEM based software ANSYS (version 15) on simply supported rectangular plate with uniformly distributed loading condition. The results obtained for two different material properties of steel and aluminium are compared by using static structural and modal analysis. The analysis result of deformation, stress and frequency at each mode on simply supported rectangular plate obtained by ANSYS are compared for two material properties. And these results are compared with regression analysis for accuracy.
\end{abstract}

Keywords-Simply supported rectangular plate, ANSYS (V15); Static analysis; Modal

analysis; Regression analysis

\section{Introduction}

Rectangular thin plates are widely used in many engineering application like roof and floor of building, foundation of footing, water tanks, turbine disk etc. Plates used in such cases are normally subjected to lateral loads causes bending of plate. Generally plates are classified in three categories i.e. thin plate, moderately thick plate and thick plate depends on their thickness. If thickness of plate is very small as compared to other two dimension is called as thin plate and if the ratio of thickness to the lesser of other two dimensions is less than 0.05 then it is considered as thin plate. Plate boundries that is prevented from deflection but free to rotate about a line along the boundary edges such as hinge is defined as simply supported edge. Along the simply supported edge the bending moment and deflection would be zero.

In the present paper a simply supported rectangular plate carrying a uniformly distributed load is considered. A general solution is obtained by finite element based analysis software. In static analysis the results obtained in form of deflection, normal stress in $\mathrm{X}$ and $\mathrm{Y}$ directions and in modal anlaysis results obtained in form of total deformation which gives frquency upto eight mode of rectangular plate. 


\section{RELATED WORK}

Ramu I and S. C. Mohanty determine the natural frequencies of an isotropic thin plate using Finite element method. The calculated frequencies have been compared with those obtained from exact Levy type solution. Based on this Kirchhoff plate theory, the stiffness and mass matrices are calculated using Finite Element Method (FEM). This methodology is useful for obtaining the natural frequencies of the considered rectangular plate. Numerical results obtained from FEM of the simply supported rectangular plates are giving close agreement with the exact solutions results [1]. Vanam B. C. L. Rajyalakshmi M. and Inala R. analyze the static analysis of an isotropic rectangular plate with various boundary conditions and various types of load applications. Finite element analysis has been carried out for an isotropic rectangular plate by considering the master element as a four noded quadrilateral element.The results obtained by finite element analysis and ANSYS simulation results are in close agreement with the results obtained from exact solutions from classical method [2]. T. Kant,K. Swaminathan presented analytical formulations and solutions to the static analysis of simply supported composite and sandwich plates hitherto not reported in the literature based on a higher order refined theory developed by the first author and already reported in the literature are presented[3]. The equations of equilibrium are obtained using principle of minimum potential energy.Solutions are obtained in closed forms using Navier's technique by solving the boundary value problem. The comparison of the results with the available elasticity solutions and results computed independently using the first order and the other higher order theories.

\section{METHODOLOGY}

A simply supported rectangular plate with uniformly distributed loading condition problem is considered. Two different material are compared that is steel and aluminium by using static and modal analysis. These plates modeled and analysed in ANSYS software. And these results of different material are compared with regression analysis.

\begin{tabular}{|c|c|c|c|c|c|c|c|c|c|c|c|c|}
\hline $\begin{array}{l}\text { Mater } \\
\text { ial } \\
\text { Prope } \\
\text { rties }\end{array}$ & $\begin{array}{l}\text { Den } \\
\text { sity }\end{array}$ & $\begin{array}{l}\text { Spe } \\
\text { cifi } \\
\text { c } \\
\text { Hea } \\
t\end{array}$ & $\begin{array}{l}\text { Therm } \\
\text { al } \\
\text { Condu } \\
\text { ctivity }\end{array}$ & $\begin{array}{l}\text { Com } \\
\text { press } \\
\text { ive } \\
\text { Ulti } \\
\text { mate } \\
\text { Stre } \\
\text { ngth }\end{array}$ & $\begin{array}{l}\text { Comp } \\
\text { ressiv } \\
\text { e } \\
\text { Yield } \\
\text { Streng } \\
\text { th }\end{array}$ & $\begin{array}{l}\text { Tensi } \\
\text { le } \\
\text { Yield } \\
\text { Stren } \\
\text { gth }\end{array}$ & $\begin{array}{l}\text { Tensil } \\
\text { e } \\
\text { Ultim } \\
\text { ate } \\
\text { Streng } \\
\text { th }\end{array}$ & $\begin{array}{l}\text { Youn } \\
\text { g's } \\
\text { Modu } \\
\text { lus }\end{array}$ & $\begin{array}{l}\text { Poiss } \\
\text { on's } \\
\text { Ratio }\end{array}$ & $\begin{array}{l}\text { Bulk } \\
\text { Modul } \\
\text { us }\end{array}$ & $\begin{array}{l}\text { Shear } \\
\text { Modu } \\
\text { lus }\end{array}$ & $\begin{array}{l}\text { Thic } \\
\text { knes } \\
\text { s }\end{array}$ \\
\hline $\begin{array}{l}\text { Struct } \\
\text { ural } \\
\text { Stee }\end{array}$ & $\begin{array}{l}7.85 \\
\text { e- } 00 \\
6 \mathrm{~kg} \\
\mathrm{~mm} \\
\wedge-3\end{array}$ & $\begin{array}{l}4.3 \\
4 \mathrm{e}+ \\
005 \\
\mathrm{~mJ} \\
\mathrm{~kg}^{\wedge} \\
-1 \\
\mathrm{C}^{\wedge}- \\
1 \\
\end{array}$ & $\begin{array}{l}6.05 \mathrm{e}- \\
002 \mathrm{~W} \\
\mathrm{~mm}^{\wedge}- \\
1 \\
\mathrm{C}^{\wedge}-1\end{array}$ & $\begin{array}{l}0 \\
\mathrm{MPa}\end{array}$ & $\begin{array}{l}250 \\
\mathrm{MPa}\end{array}$ & $\begin{array}{l}250 \\
\mathrm{MPa}\end{array}$ & $\begin{array}{l}460 \\
\mathrm{MPa}\end{array}$ & $\begin{array}{l}2 . \mathrm{e}+0 \\
05 \\
\mathrm{MPa}\end{array}$ & 0.3 & $\begin{array}{l}1.6667 \\
\mathrm{e}+005 \\
\mathrm{MPa}\end{array}$ & $\begin{array}{l}7692 \\
3 \\
\mathrm{MPa}\end{array}$ & $\begin{array}{l}100 \\
\mathrm{~mm}\end{array}$ \\
\hline $\begin{array}{l}\text { Alumi } \\
\text { nium }\end{array}$ & $\begin{array}{l}2.71 \\
9 \mathrm{e}-0 \\
06 \\
\mathrm{~kg} \\
\mathrm{~mm} \\
\wedge-3\end{array}$ & $\begin{array}{l}8.7 \\
1 \mathrm{e}+ \\
005 \\
\mathrm{~mJ} \\
\mathrm{~kg}^{\wedge} \\
-1 \\
\mathrm{C}^{\wedge}- \\
1\end{array}$ & $\begin{array}{l}0.202 \\
4 \quad \mathrm{~W} \\
\mathrm{~mm}^{\wedge}- \\
1 \\
\mathrm{C}^{\wedge}-1\end{array}$ & $\begin{array}{l}0 \\
\mathrm{MPa}\end{array}$ & $\begin{array}{l}240 \\
\mathrm{MPa}\end{array}$ & $\begin{array}{l}240 \\
\mathrm{MPa}\end{array}$ & $\begin{array}{l}290 \\
\mathrm{MPa}\end{array}$ & $\begin{array}{l}7100 \\
0 \\
\mathrm{MPa}\end{array}$ & 0.33 & $\begin{array}{l}69608 \\
\mathrm{MPa}\end{array}$ & $\begin{array}{l}2669 \\
2 \\
\mathrm{MPa}\end{array}$ & $\begin{array}{l}100 \\
\mathrm{~mm}\end{array}$ \\
\hline
\end{tabular}


TABLE I. MATERIAL PROPERTIES FOR STEEL AND ALUMINIUM

\section{RESULTS}

Static analysis

In static analysis the results calculated by ANSYS in the form of total deformation, normal stress in $\mathrm{x}$ and $\mathrm{y}$ direction for simply supported rectangular plate carrying uniformly distributed load.

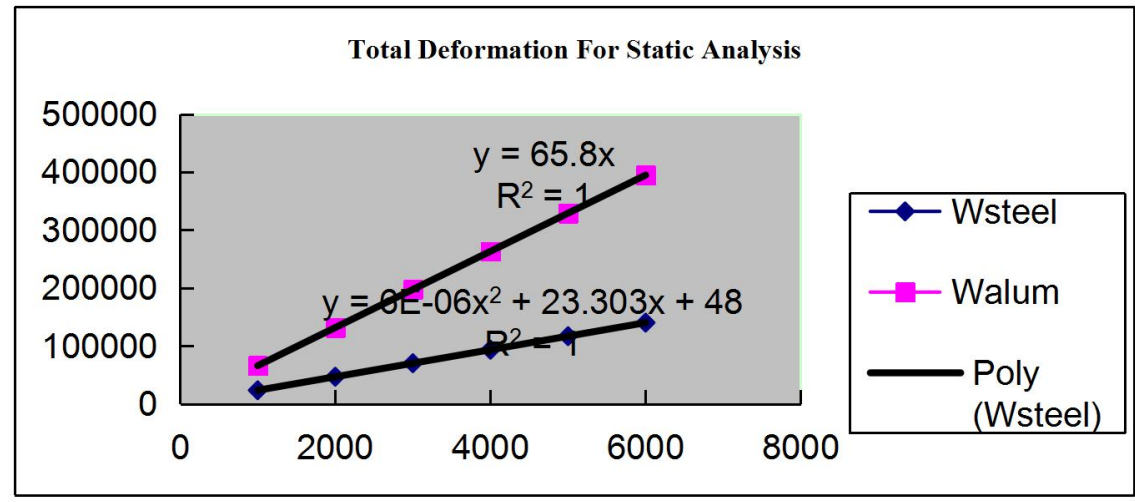

Graph.1. Total deformation in steel and aluminium plate

Graph.1 represents the difference between total deformation of steel and aluminium rectangular plate using static analysis. And the equation shown on graph using trendline equation is regression analysis.

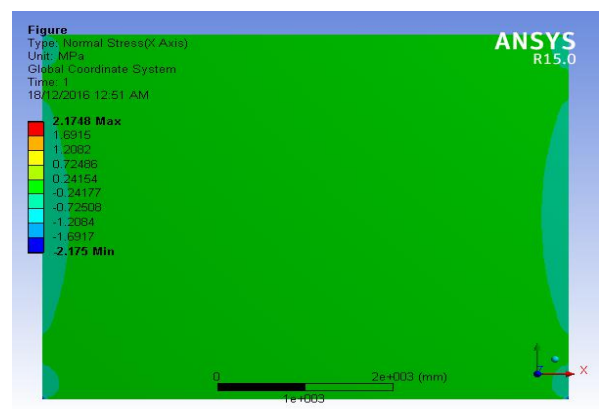

Fig. 1. Normal stress in X-direction in steel plate

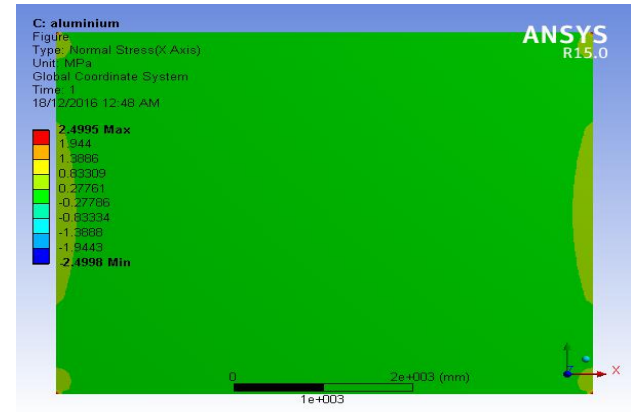

Fig. 2. Normal stress in X-direction in aluminium plate 


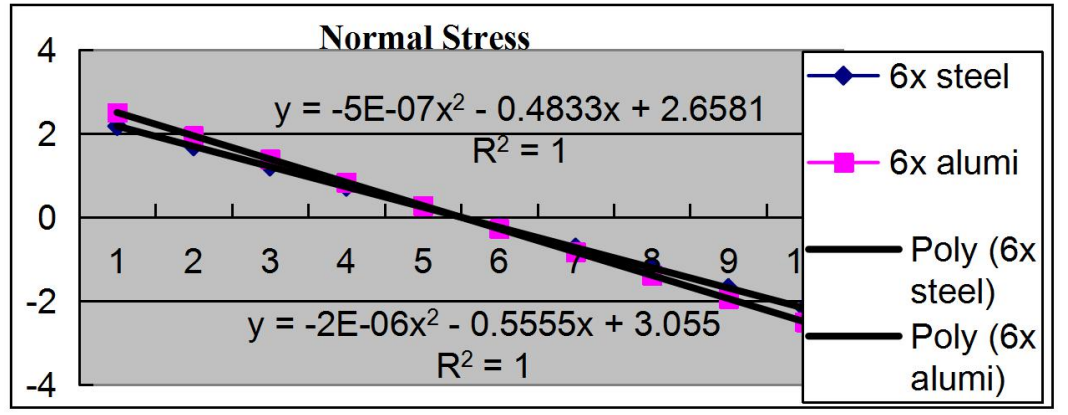

Graph.2. Normal stress in X-direction

This graph shows the variation of normal stress in $\mathrm{x}$-direction of steel and aluminium plate.

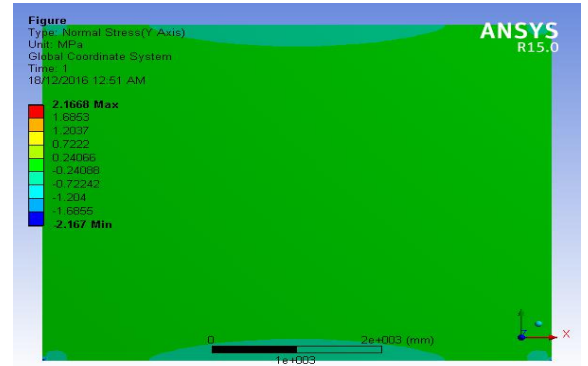

Fig. 3. Normal stress in Y-direction in steel plate

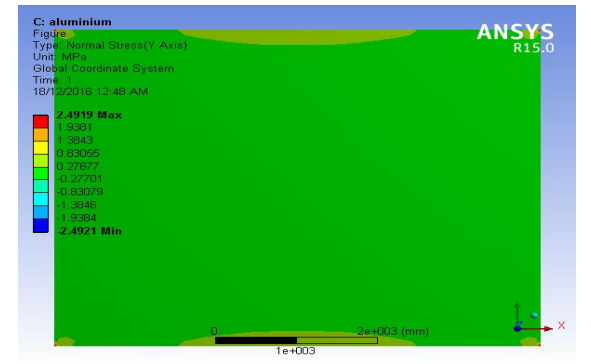

Fig. 4. Normal stress in Y-direction in aluminium plate

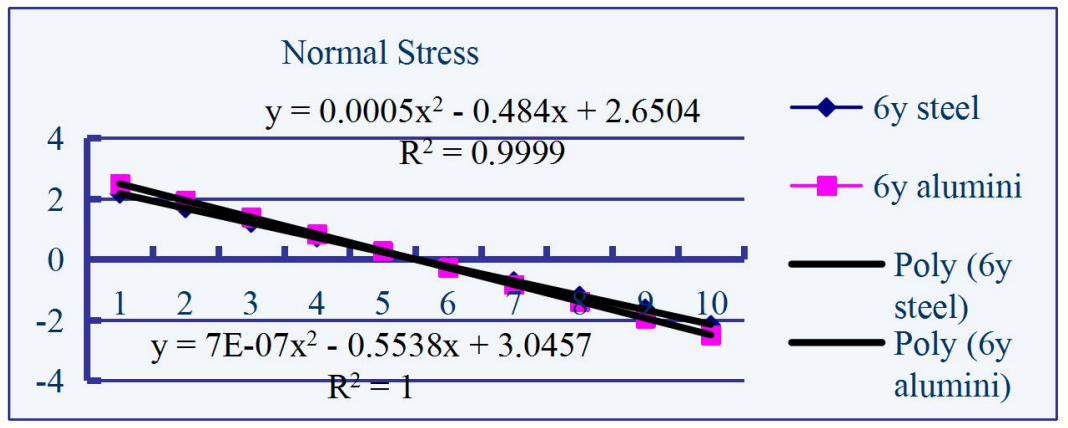

Graph.3. Normal stress in Y-direction

Graph.3. shows the variation of normal stress in y-direction of steel and aluminium plate.

Modal analysis

In modal analysis the results calculated by ANSYS in the form of total deformation upto eight mode which shows the values in the form of frequency at each mode for simply supported rectangular plate carrying uniformly distributed load.

1) For rectangular steel plate 


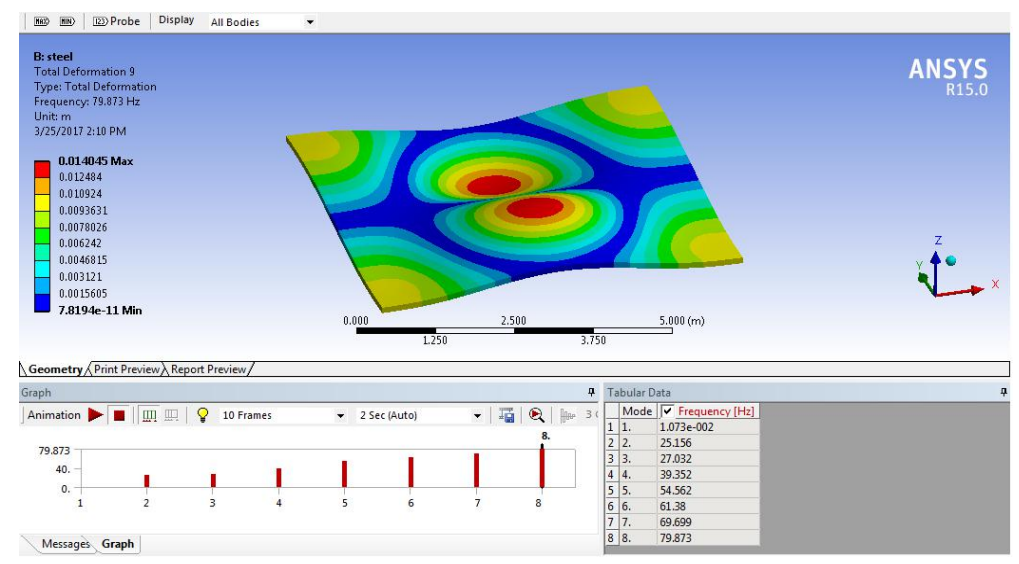

Fig. 5. Modal analysis of steel rectangular plate

From fig. 5. it shows the total deformation of steel plate from 1st to 8th mode of modal analysis.

2) For rectangular aluminium plate

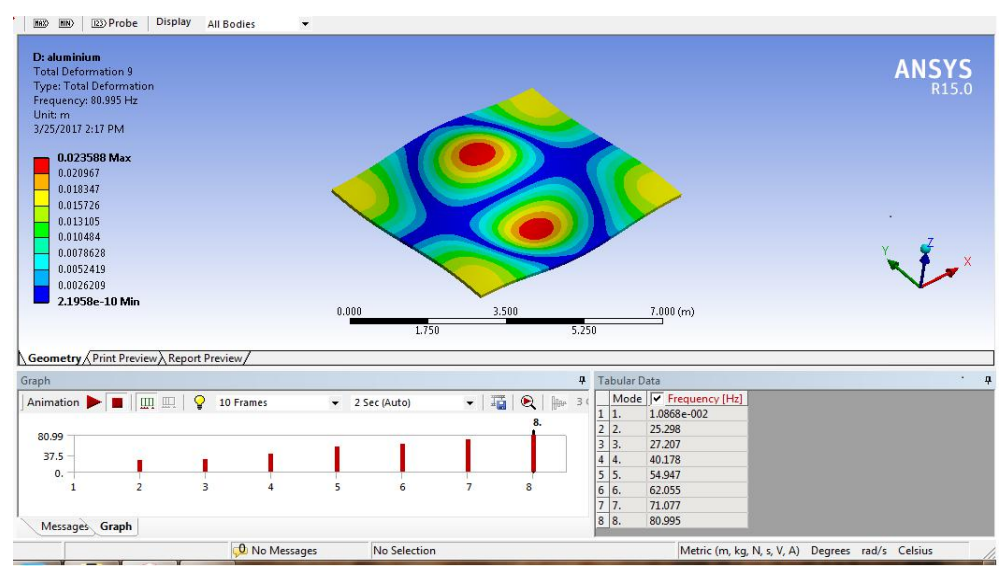

Fig. 6. Modal analysis of aluminium rectangular plate

From fig. 6. it shows the total deformation of aluminium plate from 1st to 8th mode of modal analysis.

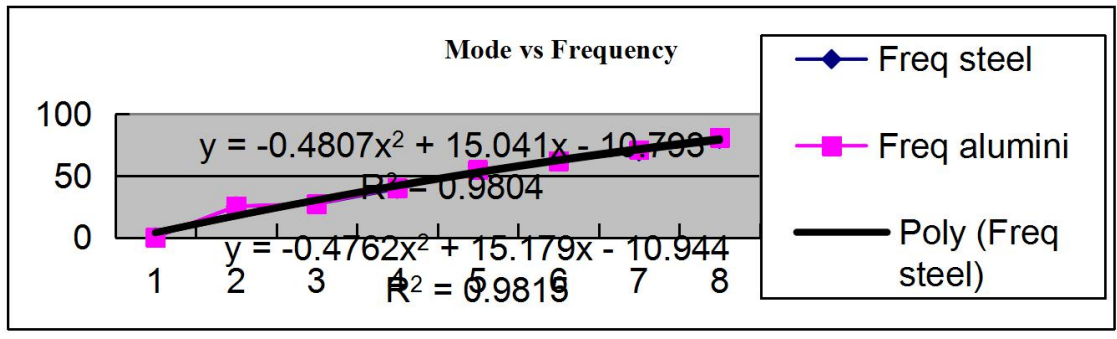


Graph.4. Mode Vs Frequency

This graph shows the difference between mode verses frequency to locate at each mode shape how many frequencies generated on steel and aluminium rectangular plate.

\section{CONCLUSION}

In this study, The finite element analysis of structural analysis were performed for all sides of simply supported rectangular plate with uniformly distributed loading condition problem for steel and aluminium material using ansys are concluded as follow:

- The total deformation of steel plate is less than the aluminium plate by static analysis and also by regression analysis. The value of regression analysis calculated on graph using trendline which gives very less value or exaxt value as nearer to the calculated value by ansys

- Normal stress results are less in steel as compared to aluminium plate in both $\mathrm{x}$ and y direction.

- The higher frequency found in aluminium plate is $80.995 \mathrm{~Hz}$ by ANSYS and $80.0112 \mathrm{~Hz}$ by regression analysis as compared to steel plate is $79.873 \mathrm{~Hz}$ ANSYS and $78.762 \mathrm{~Hz}$ by regression analysis.

- From overall results to be concluded that the steel rectangular plate is better than aluminium rectangular plate. Because, it gives minimum total deformation, normal stress and frequency in static and modal analysis as compared to aluminium rectangular plate.

\section{REFERENCES}

Ramu I and S. C. Mohanty "Study on Free Vibration Analysis of Rectangular Plate Structures Using Finite Element Method"Procedia Engineering $38 \quad(2012)$ 2758-2766doi:10.1016/j.proeng.2012.06.323

Marco Amabili and P. Balasubramanian "Experimental and numerical study on vibrations and static deflection of a thin hyper elastic plate" Journal of Sound and Vibration 385(2016)81-92

Vanam B. C. L., Rajyalakshmi M. and Inala R."Static analysis of an isotropic rectangular plate using finite element analysis (FEA) "Journal of Mechanical Engineering Research Vol. 4(4), pp. 148-162, April 2012 DOI: 10.5897/JMER11.088 ISSN 2141 - 2383 C 2012 Academic Journals

T. Kant , K. Swaminathan"Analytical solutions for the static analysis of laminated composite and sandwich plates based on a higher order refined theory"

Timoshenko SP, Woinowsky-Krieger S. Theory of plates and shells. New York: Mc-Graw Hill; 1959.

Lo KH, Christensen RM, Wu EM. A higher order theory of plate deformation, Part 2: Laminated plates. ASME J Appl Mech 1977b;44(4):669-76.

Wu L. And Liu J. Free vibration analysis of arbitrary shaped thick plates by differential cubature method, International Journal of Mechanical Sciences 47 (2005) 6381.

Tanaka M., Yamagiwa K., Miyazaki K., Ueda T. Free vibration analysis of elastic plate structures by boundary element method, Engineering Analysis, Volume 5, Issue 4, December 1988, Pages 182-188

Lu C.F., Zhang Z.C., Chen W.Q. Free vibration of generally supported rectangular Kirchhoff plates: State-space-based differential quadrature method, International Journal for Numerical Methods in Engineering, Int. J. Numer. Meth. Engng 2007; 70:1430 1450. 